\title{
The Existence of Panji Masks in Postmodern
}

\author{
Muhammad Widya Ari Wibowo ${ }^{1, *}$ Kuswarsantyo $^{1}$ Cholis Mahardika ${ }^{1}$
}

\author{
${ }^{l}$ Yogyakarta State University, Yogyakarta, Indonesia \\ *Corresponding author.Email: rayyatigarambu@gmail.com
}

\begin{abstract}
This study explores the Panji Mask in Yogyakarta. The development and shift in the function of the Panji Mask result in its unique aesthetic value due to the influence of postmodernism and can be seen in the resulting visual form. This study used a qualitative descriptive case study approach. Data were obtained through observations, interviews, and documentation. Triangulation was used for data validation, while the analysis was conducted using phenomenological observations. Based on the analysis, it can be concluded that the Panji Mask is an element of a ritual ceremony as well as dance performance in which the function has shifted into a contemporary decoration piece that serves to preserve Indonesian culture. The visual form of the postmodern Panji Mask implies the notion of deconstruction as it becomes more flexible and can be produced according to the customer's request in terms of the decoration and coloring. The Panji Mask experiences a shift into a wall art piece for room decoration.
\end{abstract}

Keywords-Panji mask, postmodern

\section{INTRODUCTION}

The story of Panji originates from the island of Java, inspired by the division of territory between the east of the Berantas river known as Jenggala and the west of the river called Panjalu in the first half of the 11th century, precisely around 20-24 November 1042, near the end of King Erlangga's rule [1]. The two sons of King Erlangga later became the king and ruler in each of these regions. The first kings in the kingdom of Jenggala were Sri Maharaja Mapanji Garasakan and Sri Samarawijaya Dharmasuparnawahana Teguh Uttungga Dewa. In the end there was a misunderstanding and enmity between the two kings which resulted in a battle between the kingdom of Jenggala against the kingdom of Panjalu. In 1135, after undergoing three changes of kings, Jenggala could be destroyed by Raja Panjalu named Sri Maharaja Mapanji Jayabhaya [2]. The name Panjalu as a kingdom later was known as 'Daha', and is now more popular as 'Kediri'.

Seni Topeng (Mask Art), also called Wayang Topeng (Mask Dance), always underwent modifications, so that it always developed and could always exist in Javanese society at that time. Its development includes forms and performances which are connected with the life of Javanese people. It also has different versions in different regions, but the meanings and stories that are presented have many similarities, one of which draws from the story of a character named Panji.

Indonesian society is very diverse, consisting of many ethnic groups and traditional beliefs. This enables the development of diversity that involves all aspects of life, including culture. This is due to the fact that each ethnic group has the creativity to create works, both related to personal interests and the public at large. The same thing applies to the tradition of mask culture, whether it is a mask that represents an ancestor, a deity, a figure, or a mask that reflects personal expression. All forms of the work's purpose and function vary according to the development of the era.

Robby Hidajat argue the Malangan Mask Dance takes the Panji story as a social function, that is, when the dance is performed to enliven hajatan (ceremonies) [3]. It can be seen here that the performance reflects a reality related to solidarity and intimacy. Second, the Malangan Mask Dance in Kedungmonggo Hamlet is staged with the belief that there is a spirit that protects the village called dhanyang desa. Third, the structural understanding of space in this dance refers to the position of four outward directions, and then returns to one point towards the inside called pancer (axis). This study found that the Malangan Mask Dance is a material object, not just a standalone artifact of art.

The world is experiencing rapid development and is now entering an era called postmodern. This era has also been affecting Indonesia, especially in the arts and culture. Postmodernism in Indonesia has had an influence on the development and existence of the Panji Mask. The appearance of the Panji Mask has changed in terms of its function and meaning. In the postmodern era, it has changed its outward appearance to meet consumer demands. Its function has also shifted to entertainment and decoration.

This article focuses on changes in Panji Mask and its existence in relation to the influence of postmodernism in Indonesia. The researchers used a qualitative approach with a case study research design. The data were collected from literature study, documentations, and interviews. The discussion in this article aims to inform readers about the changing function of the Panji Mask in the postmodern era, from ritual media to the media to support dance performances and room decoration.

\section{METHOD}

The researchers used a qualitative approach with a case study research design. This research design was used to compare the 
findings of this study with the results of other studies. The data collection techniques used were the study of literature, documentations, and interviews. The data were analyzed using interactive data analysis techniques. The study was conducted in Yogyakarta, Indonesia.

\section{RESULTS AND DISCUSSION}

This study found that Panji Mask in the postmodern era in Yogyakarta, Indonesia has experienced a shift in three areas: function, design appearance, and existence. The following are discussions of changes in the Panji Mask in the postmodern era:

\subsection{Shift in the Function of the Panji Mask}

Murgiyanto believes the mask was originally made to be used at a death ceremony where it represented the person who died, which was later considered to be a picture of ancestral spirits [4]. Meanwhile, Sumintarsih argues that, at first, masks were made as symbolic depictions of ancestral spirits and as a tribute to them as well as being used as a medium for asking their ancestors to reside in the masks [5]. In this case, the mask dance functions as an intermediary between the profane world and the sacred. Therefore, not everyone is able or permitted to wear a mask because there are certain requirements about who can wear a mask. Over time, masks are used in the mask dance. The function of the mask is not only as a work of art but also as a medium to worship, respect and meet with ancestors. This phenomenon is usually seen in rituals related to the worship of ancestral spirits. The mask here functions as a religious magical object. Ritual ceremonies that use masks as a medium for the personification of the ancestors can still be found. Here, the mask is used to perform religious rites.

Sedyawati argues that masks, also called kedhok or tapel, are known in several ethnic groups in Indonesia [6]. They have various forms and functions. Masks are objects of human culture which may be as old as human culture itself, having been known since historical times, and not only in Indonesia. In general, it can be said that masks are a form of symbolic expression made by humans for a specific purpose.

According to Soedarsono, the masks in the mask dance with the Panji story are still often used for various ritual purposes, such as to clean the village, marriage, circumcision, and even for ruwatan (excorism or purification) [7]. Likewise, the way of thinking of the people has shifted from traditional thinking to analytic and rational. The making of works of art, one of which is mask art, which is usually passed down from one generation to another based on a certain standard, has shifted toward efficiency, both technically and economically. At present, the ability of arts workers is based on their work performance, in contrast to traditional societies that use status as a benchmark for assessment. Thus, status-oriented societies will shift towards work performance. Likewise, the economic system of modern society today has shifted from traditional societies oriented towards meeting basic needs with moral and social incentives to the economic system of modern society which pursues unlimited needs with market mechanisms based on economic incentives. For this reason, hard work and work performance are required because the fulfillment of the necessities of life does not only stop at basic needs, but also covers other needs. The consumptive pattern of the community's economy has shifted towards a productive economic pattern [8].

Based on the explanation above, it can be concluded that Panji Mask can be defined as a face covering that represents a character in the Panji story. Masks play an important role in various aspects of life because they are considered to have magical and religious values. They play a large role as special symbols in various ceremonial rituals and traditional activities. Over time, masks are also used in the mask dance. Masks, as a function of art, is a symbolic expression towards the responses and impressions of life in the universe and the responses of market demand. Apparently, the latter is a fertile ground that motivates mask crafters to carry out their mask production activities. Without market or consumer demand, mask crafters cannot produce well. As for the Panji Mask as an aesthetic function, masks are no longer made to support the show but are used only to decorate the room.

The development of art basically follows the process of change that occurs in a particular culture in society. As a work of art, masks are cultural products made with symbols and expressions that describe certain manifestations or characters. In its development, mask art, both in terms of its forms, functions, and ritual values, has undergone a change or shift. This change is due to the changing needs of society from time to time, especially if we look at culture in general where the era has changed from agrarian to industrial. Even though Indonesia is not yet fully an industrial country, in reality, its people have been flooded with industrial products from developed countries, such as Japan, America and Russia. Such a situation is very influential on the existence of traditional art, which is forced into a state of transition or at a crossroads [10]. Broadly speaking, it can be said that traditional art, especially mask art, in terms of its function and ritual value has begun to shift or weaken in accordance with the development of the culture of the people in the current postmodern era. Originally, masks functioned as sacred objects related to religious beliefs, but now they have shifted to artistic and aesthetic functions.

\subsection{The Design Appearance of Panji Mask}

Alusan (male, refined) masks have a motion called alus (refined) while gagahan (male, strong) masks has gagahan movement (strong). Meanwhile, masks for the goddess are called putren and those for the servants are called gicul. Initially, the masks did not have a jamangan (tiara-like crown, worn around the forehead to the side of the head) but the dancers used real crowns that were worn over the head. Lately, masks are not only worn when dancing, but they can also be used as hanging decorations in the room, so the masks with jamangan are made by craftsmen. So, when the mask is hung, it looks attractive, not too plain like when it does not have any jamangan.

According to Soedarsono, the Panji mask follows the shape of the gedhog shadow puppet's face which is similar to the purwa shadow puppet's face [7]. The disposition system is determined by the shape of the face and the color and shape of the eyes, nose and mouth. Evil figures like Prabu Klana Suwandana, Panji's enemy, masked in red with large and frightening eyes, protruding nose, and open mouth showing large teeth and mustache. The mask for Panji, a knight, was very light blue with narrow eyes, small nose, slightly open mouth, and no mustache. Arrogant and delicate knights like Gunungsari have a thin mustache. The punokawan mask of Panji, Bancak and 
Doyok, or Pentul and Tembem, does not have a lower jaw and is cute in shape. Bancak's mask is white while Doyok's mask is black.

Based on an interview with Supana, Panji Mask Crafters in Yogyakarta, characters in Panji Mask can be divided into three elements that can be distinguished and can be seen in plain sight, namely 1 . the tip of the eye line, 2 . the nose, and 3 . the mouth. The characters in the mask are pseudo in nature, a momentary expression that is not permanent and can still change. Masks can describe three characters, for example sad characters, happy characters, and angry characters. Sad characters have flat eye lines or even have the outer eye edges curved down with the right and left ends of the mouth also curved downward. A happy character has a curved tip of the eye, while the lip tends to be stretched upward. Meanwhile, angry characters can be seen from the tip of the eye which tends to tilt upward with the right and left ends of the mouth curved down.

The mask is full of philosophical meanings for the lives of Javanese people. Each Javanese person has four characters that are visualized in the form of colors: aluamah (hunger, desire for food and drink), anger (aggression, lust for power), supiah (greed, desire for property), and mutmainah (the passion for tranquility, desire for inner peace). The colors that represent the characters respectively are black, red, yellow, and white. The mask is full of Javanese philosophy; the Panji figure is a depiction of the mutmainah character in white, a color that cannot be seen with the eye but can be felt. Our ancestors embodied, created, and visualized an invisible character that was manifested in the form of a puppet depicting the character, not the figure. The Panji Mask is part of a puppet which is an embodiment of the invisible character earlier. According to Supana, past artists have thought that the mask is a propagation, guidance and guidelines for life.

\subsection{The existence of Panji Mask in postmodern in Yogyakarta, Indonesia.}

The development of mask craft in Yogyakarta is quite rapid as evidenced by the establishment of mask craft businesses, one of which is in the hamlet of Diro, Pendowoharjo, Sewon, Bantul, Yogyakarta. In this area, some people rely on their lives as craftsmen of souvenirs made from wood, one of which is the Panji Mask. An effort to preserve Supana Taman Sari's classic mask craft by Supana still exists and it maintains the authenticity of its trademark.

The use of wood raw material used for jaranan (horse dance) is a typical material used to make Panji masks because, although a little rare, the quality is very good and it is proven to be stronger and more durable than other materials. Therefore, it is not surprising that many mask enthusiasts come to see, learn and even often ask to take part in activities as instructors at the Yogyakarta Education and Culture Office, or outside Java (Kalimantan), to take part in exhibitions held in Yogyakarta and beyond.

This classic wooden mask craft has been pioneered since 1920 by the grandfather of Supono, one of the Panji Mask crafters in Pendowoharjo, Sewon, Bantul. As a craftsman and preserver of Indonesian culture related to the production of classical wooden masks, Warno Waskita did not escape the attention of great figures in Indonesia. During the New Order era, Indonesian President Suharto invited Warno Waskito to come to the state palace because the president wanted to learn firsthand the process of making a classic wooden mask. As historical evidence, Warno Waskito's grandfather still kept a photo of President Soeharto with him, which was signed by President Soeharto. To this day, it is still stored well in the display cabinet along with his classic wooden mask.

After the death of Warno Waskito, Supana often sought inspiration by observing people passing by in the market until one day he found an inspiration that visually, the human character lies in the eyes, nose and mouth. Since that time, Supana, in addition to pursuing the manufacture of wooden masks, which is famous for prioritizing characters, also took part in youth activities by joining dance, drama and puppet groups. Since entering this puppet group, Supana felt he received supports in the form of ideas and insights in making masks with various characters including Panji mask characters based on the story of the gedhog puppet. In its development, Supana (Pono Wiguno) in addition to making wooden masks, also produced masks with cement paper material and sawdust. Furthermore, he made leather puppets and mask puppet accessories (necklaces and sumping/ear ornament) to meet the demands of domestic and foreign collectors and to be used alone in the performance. This is done in collaboration with pedhalang in Yogyakarta. This is done to preserve traditional arts in the community, especially in youth groups, so that the Panji Mask will not become extinct in the future.

According to Supana (interview with Supana, Panji Mask crafters in Bantul district, Yogyakarta, Indonesia), related to the existence of Panji Mask, there was a shift in function from what used to be a ritual medium to only as a medium for dance performances and also as room decoration.

\subsubsection{Mask as a ritual mediator}

In the beginning, the Panji Mask was used in death ceremonies. It represented the person who had died, which was then made as a depiction of the spirits of the ancestors. The mask was also a symbol of respect for the spirits of the ancestors, which was used as a medium to invite the ancestors to reside in the mask. In this case, the puppet mask functioned as an intermediary between the profane world and the sacred. Therefore, not everyone could or was permitted to wear a mask because there were certain requirements regarding who were allowed to wear a mask. Over time, masks are used in mask puppet art.

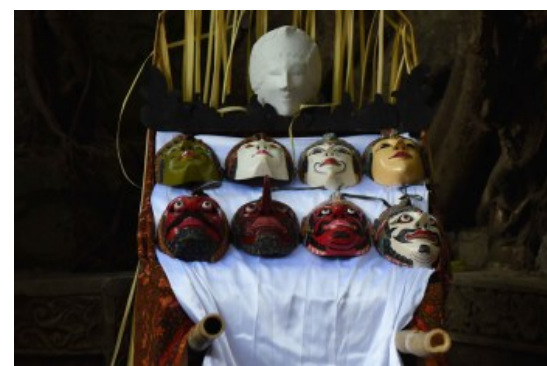

Figure 1 Panji Mask used in a traditional ceremonial ritual.

Panji masks are seen not only as objects of art but also as a medium of worship, respect and meeting with their ancestors. This phenomenon is commonly seen in ritual ceremonial activities related to ancestor spirit worship. The mask here functions as a religious magical object. The ritual ceremony with a mask as a medium for the personification of the ancestors can still be found today. Here, the mask is used to perform religious rites. 


\subsubsection{Mask as a Property on dance performances}

As a supporting media for dance performances, Panji Mask is used to strengthen characterizations of characters in the Panji story play, and the core of the Panji story is about heroism and romance between Panji Asmarabangun and Dewi Sekartaji. Meanwhile, the mask functions as a face covering, and Panji is a title given to a knight, so that there are more than one knight having the first name Panji, although their last names (the real ones) are different, for example Panji Asmarabangun, Panji Inu Kertopati, Panji Sinom Perdopo, and Parang Carang Waspo. The term Panji is also used as a pseudonym by a knight in a description, so that the Panji mask is one person with several characters (wanda or polatan, in Javanese).

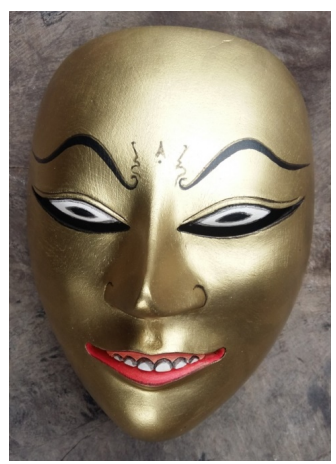

Figure 2 Pandji Mask used as Property on Dance Performances.

The function of the Panji Mask in particular as a property in mask dance performances is to reinforce the character of a dancer. The mask is very useful to maintain the character when dancing in a live performance, that is, if a dancer is disturbed by the audience, or in cheers, the dancers' laughter and facial expressions will not be seen because it is covered by a mask, so the character's face will not change.

\subsubsection{Msk as a function of aesthetic art}

The creation of art intended for the outside community is called the art of acculturation, that is, the tourist art. What is meant by art of acculturation is art whose presence in the community is a new product resulting from the creativity of artists or craftsmen in anticipation of the presence of tourists. In creating works of art like this, there is a combination or acculturation between the tastes of the creator with the tastes of the market or tourists. Because this art is created for tourists, it is then called tourist art [9].

The generation that lives in the postmodern and information era must be creative and innovative. Craftsmen must learn more from these developments and must not be easily satisfied because otherwise it will eventually stop at a certain point of success and disappear as time changes. The development in all sectors of life is very complex and difficult to predict, especially the development of art which is always exploding at any time looking for new discoveries. Mask crafters must be able to anticipate the symptoms of these changes so they are not outdated. In addition, they must also be able to utilize modern technology to support their production. Panji masks that are used for decoration are often accompanied by accessories on masks, for example jamangan, and are usually adjusted according to consumer requests. The addition of accessories does not affect the character of the mask.

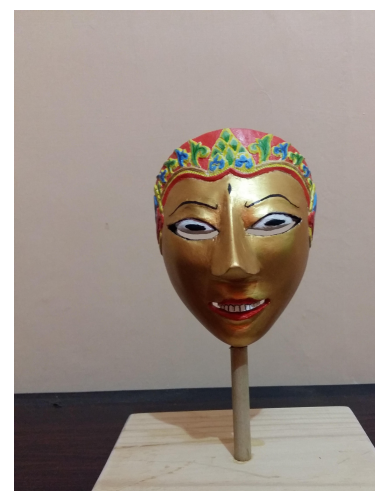

Figure 3 Panji Mask in Postmodern Era as a Function of Aesthetic Art

Panji masks in the postmodern era display a variety of styles namely primitive, ancient, antic, traditional / classical, and free styles that are not bound by the standard rules that exist in traditional masks. In terms of shape, the Panji Mask in the postmodern era also experienced changes in shape such as free/expressive and formal/regular shapes and sizes. In the case of free-form masks, people are more familiar with modern masks or creations that can be in the form of past masks made for commercial economic purposes or as a form of cultural preservation. Its form can be in the form of long or ornamental objects, or as a game instrument or show attribute in a show. Until now the Panji Mask is still used for a variety of daily artistic and traditional activities, but not infrequently some of the panji masks are used as decoration materials.

\section{CONCLUSION}

The Panji Mask in the postmodern era experienced various shifts in function. Originally, Panji Mask was used as a medium for religious rituals but its function has now changed to become an art medium. Panji masks become media that support dance to strengthen characterizations of characters in Panji stories. The visual form of the Panji Mask for dancers can now also be ordered according to the wishes of consumers. In the postmodern era, Panji Mask has also changed its function, which is to decorate the room.

\section{REFERENCES}

[1] Sumaryono. (n.d). Seni, Karya Sastra Panji, dan Seni Pertunjukan. [Arts, Panji Literature Work, and Performing Arts]. MA.http://digilib.isi.ac.id/4686/

[2] Muljana, Slamet. Nagarakretagama dan tafsir sejarahnya [Negarakertagama and its history Interpretation]. Bhratara Karya Aksara, 1979.

[3] Hidajat, Robby. "Struktur, Simbol, dan Makna Wayang Topeng Malang [Structure, Symbols, and Meanings of Malang Mask Puppets]." dalam Jurnal Bahasa dan Seni 2 (2005). Retrieved from http://sastra.um.ac.id/wp- 
content/uploads/2009/10/Struktur-Simbol-dan-MaknaWayang-Topeng-Malang-Robby-Hidajat.pdf

[4] Murgiyanto, Sal, and A. M. Munardi. Topeng Malang: pertunjukan dramatari tradisional di daerh Kabupaten Malang [Traditional Dance Drama Performances in Malang Regency]. Proyek Sasana Budaya, Direktorat Jenderal Kebudayaan, Departemen Pendidikan dan Kebudayaan, 1980.

[5] Sumintarsih. Wayang topeng sebagai wahana pewarisan nilai [Puppet Mask As a tool of Inheritance Value]. Kementerian Pendidikan dan Kebudayaan, Balai Pelestarian Sejarah dan Nilai Tradisional Yogyakarta, 2012.

[6] Sedyawati, Edi. Seni Pertunjukan Indonesia [ Indonesia's Performing Arts]. Jakarta: PT. Gramedia Widiasarana Indonesia 1993.

[7] Narawati, Tati. Dramatari di Indonesia, kontinuitas dan perubahan [Dance Drama in Indonesia, continuity and change]. Gadjah Mada University Press, 2011.

[8] Sujatmoko, Jujun S. Suriasumantri, and S. Soedjito. Masalah sosial budaya tahun 2000: sebuah bunga rampai [Socio-cultural problems of 2000: a pastiche] . Tiara Wacana, 1986.

[9] Sudarsono. Penerapan Metode Kualitatif Dalam Penelitian Seni [Qualitative Methods in Art Research]. Makalah Seminar FPBS IKIP Yogyakarta. 2001

[10] Hadi, Sumandyo. "Perkembangan Tari Tradisional: Usaha Pemeliharaan Kehidupan Budaya [The Development of Traditional Dance: Efforts to Maintain Cultural Life]" dlm. Soedarso, ed." Perkembangan Kesenian Kita.

[11] Hermanu. Panji dari Bobung [Panji from Bobung]. Yogyakarta: Bentara Budaya Yogyakarta, 2012. 